\title{
EDITORIAL
}

\section{En recuerdo del Dr. George Cherry y su estela}

\author{
J. Javier Soldevilla-Agreda \\ Director del GNEAUPP \\ Director de GeROKомоS
}

Cuando recibes la noticia de la pérdida de algún conocido, de forma natural y aprendida vengo volviendo la vista a la huella que esa persona ha podido dejar en su mundo, en nuestro mundo, en el Mundo, por discreto o anónimo que haya podido parecer. Conocer, transcurrido un tiempo, el fallecimiento del Dr. Cherry, fundador del European Pressure Ulcer Advisory Panel (EPUAP), me ha dictado espontáneamente este panegírico sobre alguien que dejó una impronta en el movimiento científico europeo para combatir, con armas modernas, un problema de siempre, devaluado e invisibilizado, -como tantas veces hemos aludido con esos términos a las úlceras por presión.

Nuestro GNEAUPP había dado sus primeros pasos cuando recibimos la invitación de una persona, hasta entonces desconocida para nosotros, habitantes latinos de la Europa meridional, un dermatólogo responsable de una unidad de heridas en un prestigioso hospital de Oxford, que nos invitaba a acudir a la reunión fundacional de una sociedad científica que buscaba agrupar a todos los movimientos profesionales, académicos, científicos, relacionados con estas lesiones a nivel de todo el Viejo Continente. La convocatoria, lacónica, prosaica, breve, hablaba de la intencionalidad de dar vida a ese movimiento y nos convidaba a presentar, en esa jornada de no recuerdo qué mes de 1996, la situación de las úlceras por presión en nuestros distintos países y la dinámica de los grupos a los que representábamos. Todavía resuena en mí la grabación de mi presentación traducida a un correcto inglés por mi amigo Pepe Jiwani y que cientos de veces taladraron los oídos francófonos del que suscribe, animado por el sentido capital de la iniciativa y que trascendía a todos los miedos, prudencias o timideces, impuestos por el idioma, la envergadura del proyecto y la no infrecuente humildad de muchos de nosotros en marcos internacionales. Un hotel de las inmediaciones del aeropuerto de Heathrow en Londres fue el escenario para aquel encuentro, capital e iniciático de un movimiento continental todavía perdurable y que el Dr. George Cherry capitaneó durante tiempo, como presidente, y más tarde como secretario y tesorero.

Ahí comenzó una relación que puedo calificar siempre de cordial y fructífera, de relación entre profesionales, aspirantes a amigos, desde un manifiesto respeto a las diferencias entre disciplinas, y sobre todo, siempre de colaboración.

Quiero recordar también la participación como alumno en aquellas primeras escuelas de verano que organizó en su ciudad de residencia, en la ancestral universidad de habla inglesa más antigua del mundo, alojándonos en el tradicional St Anne's College de la Universidad de Oxford, en aquellos cuartos estudiantiles que te retrotraían a épocas pretéritas, atravesando temprano sus jardines para acudir al desayuno, paseando por las aguas de los ríos de Oxford en una barca de fondo plano al final de la jornada o disfrutando después de la última sesión científica del encuentro de una temprana cena amenizada por nińos con un repertorio dulce y ruidoso de danzas irlandesas, pero sobre todo acariciando el testimonio de las personas más iluminadas en esta área del saber.

Comunicarse con George, un bostoniano en la Corte del Rey Arturo, con un inglés tan áspero como rápido, ante un eterno aprendiz de aprendices de la lengua de Shakespeare, no era fácil, pero nunca fue obstáculo para caminar, para crecer, para inspirar acciones de unos en los otros y para sentirnos siempre orgullosos de haber participado en aquella primera fragua de la EPUAP.

Nos hemos visto muchas veces en eventos científicos en toda Europa, acompañado a menudo por su esposa Christine, quienes durante años sostuvieron la secretaría de la Sociedad Europea, y siempre un saludo cortés y una sonrisa, de un tipo, del que tengo la sensación que no las prodigaba.

En estos veinte años, el Dr. Cherry, voz autorizada en el ámbito clínico desde su Unidad, pionera en investigación y formación en la materia cuando apenas nadie lo hacía, desde la dirección de la Sociedad, quizá sojuzgado en los últimos años por una dedicación paternalista, pero creo firmemente recta y leal, la huella de su figura, merece hoy un homenaje, que le rendimos desde aquí, desde esta tribuna, desde este país.

Por el credo del papel relevante que ha supuesto su obra en el devenir de las úlceras por presión como un verdadero problema de salud, el pasado mes de mayo de 2014, el Grupo Nacional para el Estudio y Asesoramiento en Úlceras por Presión y Heridas Crónicas nombró Miembro de Honor al Dr. George Cherry. Ya no pudo venir a Madrid a recogerlo. La salud no le acompañaba. No sabíamos que su final estaba tan próximo y nos alegramos de haber tenido la lucidez para este reconocimiento.

Gracias, George, en nombre de esta comunidad científica. La condición de Miembro de Honor de nuestro humilde Grupo nunca la perderás, como tampoco un espacio en nuestro recuerdo.

De bien nacidos es ser agradecidos.

In memoriam 